\title{
PENGEMBANGAN MATERI AJAR MATA KULIAH APRESIASI DRAMA MELALUI PENGGALIAN NILAI-NILAI PENDIDIKAN KARAKTER NASKAH DRAMA PANEMBAHAN RESO KARYA W.S. RENDRA
}

\author{
Edy Suryanto
}

FKIP Universitas Sebelas Maret

\begin{abstract}
The purpose of this study is to describe the values of character education to develop teaching and learning materials for Drama course. It is a qualitative descriptive study by using Research and Development design. The data were obtained from the play entitled Panembahan Reso, written by W.S. Rendra by looking at the settings, the characters, the plots and some relevant documents. The technique used to collect the data was by document analysis technique. The results of the data analysis using interactive data analysis indicate that the values of character education are reflected throught the characters and their characterization; the values represented include the attitudes of being religious, hard working, peaceful, democratics, caring, fond of reading, responsible, having national spirit and excellence recognition.
\end{abstract}

Keywords: drama generic stucture, character education, drama script, educational values

\begin{abstract}
Abstrak: Penelitian ini bertujuan mendeskripsikan nilai-nilai pendidikankarakter naskah drama untuk pengembangan materi ajar mata kuliah Apresiasi Drama. Penelitian deskriptif kualitatif ini menggunakan pendekatan R \& D. Subjek penelitian adalah naskah drama Penembahan Reso karya W.S. Rendra. Sumber data diperoleh dari tempat dan peristiwa, informan, naskah drama, dan dokumen. Pengumpulan data menggunakan teknik analisis dokumen. Hasil penelitian disimpulkan bahwa nilai-nilai pendidikan karakter naskah drama ditampilkan melalui watak tokoh dan penokohan, antara lain nilai: religius, kerja keras, cinta damai, demokratis, peduli sosial, gemar membaca, tanggung jawab, semangat kebangsaan, dan menghargai prestasi.
\end{abstract}

Kata Kunci: struktur drama, pendidikan karakter, naskah drama, nilai-nilai pendidikan

Di Indonesia, drama adalah salah satu bentuk karya sastra yang digemari masyarakat luas. Bahkan hampir setiap masyarakat di setiap pelosok dunia telah akrab dengan drama. Hal ini 
disebabkan drama memiliki keistimewaan tersendiri bila dibandingkan dengan genre sastra lainnya. Dalam puisi dan prosa (seperti cerita pendek dan novel), pembaca dapat langsung menikmati karya tersebut karena pengarang langsung menghidangkan kepada pembaca. Berbeda dengan drama, dalam genre sastra ini pengarang memberi ruang kepada pembaca berimajinasi. Diterbitkannya novel atau cerita prosa bertujuan agar dinikmati pembaca dan pembaca yang menikmati karya tersebut adalah pembaca individual. Lain halnya dengan drama, ia diciptakan untuk dipentaskan dan dinikmati secara bersama-sama (Dewojati, 2012: 16).

Melalui karya sastra, pengarang dapat menuangkan segala gagasan yang dimilikinya, misalnya berupa pesan nilai-nilai pendidikan karakter. Nilai-nilai pendidikan karakter itu banyak muncul dalam karya sastra. Segala sesuatu dalam kehidupan yang tidak sesuai harapan dapat menjadi sumber inspirasi bagi pengarang dalam menciptakan karya sastra. Pengalaman berpikir pengarang yang disampaikan melalui bahasa yang khas itu mampu membangkitkan imajinasi, menggugah rasa, dan pemikiran pembaca. Melalui contohcontoh karya naskah drama terpilih, Sayuti (dalam Toha-Sarumpaet, 2002) menjelaskan urgensi sastra sebagai sumber nilai moral juga dapat mempertajam kesadaran sosial dan religius pembaca.

Naskah drama Panembahan Reso karya W.S. Rendra merupakan salah satu naskah drama yang mengangkat tema tentang suksesi yang di dalamnya terdapat muatan nilai-nilai pendidikan karakter. Hal ini tidak aneh, sebab naskah itu ditulis pada masa orde baru ketika masih berkuasa. Kajian naskah drama ini diharapkan dapat memberikan sumbangan pemikiran dalam analisis kandungan nilai-nilai di dalamnya, utamanya sebagai salah satu referensi bagi mahasiswa dan dosen pengajar sastra. Makin banyak naskah drama yang dikaji maka makin banyak pula nilai yang dapat dipahami oleh mahasiswa untuk kepentingan berkatarsis. Toha-Sarumpaet (2002), mengemukakan paparan kunci yang disampaikan oleh Ditjen Dikdasmen - Indra Djati Sidi - sesungguhnya berlandas tumpu pada karya sastra yang diperbin-cangkan itu pada hakikatnya dapat membangun kemanusiaan dan kebudayaan, melahirkan masyarakat yang mampu berpikir mandiri dan sanggup mengekspresikannya dengan baik.

Kajian naskah drama yang penuh dengan nilai-nilai pendidikan karakter dapat memberikan banyak manfaat bagi pembaca. Hasil akhir penelitian ini adalah diterbitkannya sebuah buku yang dapat dijadikan sebagai salah satu literer yang berguna bagi pengembangan materi ajar mata kuliah Apresiasi Drama.Terlebih lagi penelitian terhadap naskah drama seperti ini masih sangat jarang dilakukan sehingga hasil kajian pada naskah drama terpilih ini bisa memberikan wawasan bagi pelajar, mahasiswa, dan pembaca umum.

Pembelajaran mata kuliah Apresiasi Drama diperkirakan memegang peran penting dalam pembentukan karakter peserta didik, baik siswa maupun mahasiswa. Dalam penelitian ini, naskah drama PanembahanReso karya W.S. Rendra dikupas dari sisi nilainilai pendidikan karakter yang diharapkan dapat menjadi materi ajar untuk mendukung program pelaksanaan pendidikan karakter yang dicanangkan oleh pemerintah.

Sesuai dengan latar belakang dan permasalahan penelitian, maka tujuan umum penelitian ini adalah untuk mendapatkan nilai-nilai pendidikan karakter dan aspek-aspek lain di sekitarnya sehingga akan diperoleh simpulan bahwa hasil penelitian ini akan memberikan sumbangsih bagi kemajuan mata kuliah Apresiasi Drama. Selain itu, tujuan khususnya adalah terwujudnya materi ajar berisi teori dan hasil kajian nilai pendidikan karakter naskah drama. 
Karakter adalah cara berpikir dan berperilaku yang menjadi ciri khas tiap individu untuk hidup dan bekerja sama, baik dalam lingkup keluarga, masyarakat, bangsa dan negara. In-dividu berkarakter baik adalah individu yang bisa membuat keputusan dan siap mempertanggungjawabkan tiap akibat dari keputusan yang ia buat (Suyanto, 2010: 1). Selanjutnya, Sudrajat (dalam Suwandi, 2011: 2), mengemukakan bahwa karakter merupakan nilai-nilai perilaku manusia yang berhubungan dengan Tuhan Yang Maha Esa, diri sendiri, sesama manusia, lingkungan, dan kebangsaan yang terwujud dalam pikiran, sikap, perasaan, perkataan, dan perbuatan berdasarkan norma-norma agama, hukum, tata karma, budaya dan adat istiadat.

Sejalan dengan pengertian di atas, Sudrajat (2010: 2) menjelaskan bahwa pendidikan karakter adalah suatu sistem penanaman nilai-nilai karakter kepada warga sekolah yang meliputi komponen pengetahuan, kesadaran atau kemauan, dan tindakan untuk melaksanakan nilai-nilai, baik terhadap Tuhan Yang Maha Esa, diri sendiri, sesama, lingkungan, maupun ke-bangsaan sehingga menjadi insan kamil. Pendidikan karakter di sekolah, semua komponen (stakeholders) harus dilibatkan, termasuk komponen pendidikan itu sendiri, yaitu isi kurikulum, proses pembelajaran dan penilaian, kualitas hubungan, penanganan atau pengelolaan mata pelajaran, pengelolaan sekolah, pelaksanaan aktivitas atau kegiatan kokurikuler, pemberdayaan sarana prasarana, pembiayaan, etos kerja seluruh warga, dan lingkungan sekolah.

Terlepas dari berbagai kekurangan dalam praktik pendidikan di Indonesia, apabila dilihat dari standar nasional pendidikan yang menjadi acuan pengembangan dan implementasi pembelajaran dan penilaian di sekolah, tujuan pendidikan nasional sebenarnya dapat dicapai dengan baik. Pembinaan karakter juga termasuk dalam materi yang harus diajarkan dan dikuasai serta direalisasikan oleh peserta didik atau mahasiswa dalam kehidupan sehari-hari. Permasalahannya, pendidikan karakter di tingkat akademis selama ini barangkali baru menyentuh pada tingkatan pengenalan norma atau nilai-nilai, dan belum pada tingkatan internalisasi dan tindakan nyata dalam kehidupan sehari-hari.

Internalisasi pendidikan karakter ini berimplikasi pada pembentukan perilaku. Menurut Zamroni (dalam Zuhdi, 2011: 166-167), perilaku itu dapat berwujud menghormati dan menghargai orang lain (respect), keterbukaan dan adil (fairness), dan memiliki kepedulian (caring). Seseorang yang telah terbentuk karakternya atas tiga nilai tersebut memiliki ciri khas yang diaktulisasikan dalam perilaku, seperti: menghormati dan menghargai orang lain tanpa memandang latar belakangnya, menjunjung tinggi martabat dan kedaulatan orang lain, dan memiliki sikap toleransi yang tinggi; mudah menerima orang lain tanpa memandang latar belakangnya, dan senantiasa mengedepankan keadilan; dan kepedulian terhadap kondisi penderitaan orang lain dengan kasih sayang dan ikhlas membantu bagi yang membutuhkan.

Dalam pembentukan karakter mahasiswa, berbagai nilai tersebut di atas itu saling melengkapi. Untuk itu, dalam pembinaannya - Santrock (1995: 286-287) menyarankan hendaknya mempertimbangkan perkembangan moral berkaitan dengan aturan dan konvensi tentang apa yang seharusnya dilakukan seseorang dalam interaksinya dengan orang lain. Melalui pertimbangan ini perlu dikondisikan iklim pembelajaran yang mengatur tumbuhnya berbagai nilai itu. Iklim pembelajaran dengan cara menugasi mahasiswa mengkaji nilai-nilai pendidikan karakter pada sebuah naskah drama diharapkan dapat membantu mengembangkan potensi-potensi unik yang dimilikinya. Potensi unik yang dimaksud itu di antaranya saling membantu teman yang memiliki kelemahan dalam cara berpikir dan mengambil keputusan, saling menghargai antarteman bahwa di balik 
kelemahan tersebut tentu terdapat kelebihan pada sisi yang lain sehingga hal tersebut memungkinkan untuk menciptakan sikap saling bekerja sama.

\section{METODE}

Penelitian deskriptif kualitatif ini menggunakan pendekatan penelitiandan pengembangan (R\&D) dari Gall, Gall \& Borg (2003). Penelitian ini merupakan bagian dari penelitian Kajian Struktural, Kritik Sosial, dan Nilai Pendidikan Karakter Naskah Drama Panembahan Reso Karya W.S. Rendra untuk Pengembangan Materi Ajar Mata Kuliah Apresiasi Drama di Perguruan Tinggi yang dilaksanakan selama dua tahun dengan menggunakan langkah-langkah penelitian yang dipadatkan. Pada tahun I (2015) meliputi langkah (1) studi pendahuluan atau eksplorasi dan (2) mendesain materi ajar; sedangkan pada tahun II (2016) meliputi langkah (3) pengujian model dan (4) sosialisasi produk.

Penelitiantahun I ini dilaksanakan di Program Studi Pendidikan Bahasa Indonesia, FKIP Universitas Sebelas Maret. Alasan pemilihan tempat penelitian adalah pada program studi ini jarang dilakukan penelitian sejenis dan sebagai sarana untuk mengembangkan materi ajar mata kuliah Apresiasi Drama.

Pada penelitian ini digambarkan keadaan subjek penelitian berdasarkan fakta. Karena itu, pelaksanaan penelitian tidak terbatas pada penyajian data semata, tetapi meliputi analisis dan penafsiran terhadap data. Pendeskripsian secara rinci dan mendalam mengenai potret kondisi tentang apayang sebenarnya terjadi di lapangan studinya (Sutopo, 2002: 111). Untuk itu, dalam penelitian ini dideskripsikan hasil kajian nilai-nilai pendidikan karakter yang ditemukan pada naskah drama sebagai pengembangan materi ajar mata kuliah Apresiasi Drama

Penelitian ini berbentuk penelitian pustaka yang membahas tentang nilai-nilai pendidikan karakter pada sebuah naskah drama dan sekaligus mengembangkan hasil penelitian ini sebagai materi ajar. Subjek penelitian adalah naskah drama Panembahan Resokarya W.S. Rendra diterbitkan oleh Pustaka Karya Grafita Utama, tahun 1988. Sumber data adalah tempat dan peristiwa, informan, naskahdrama, dand okumen yang berkait dengan pembelajaran Apresiasi Drama. Pengumpulan data dengan cara observasi, wawancara, dan analisis dokumen.

Ujivaliditas data dilakukan dengan cara triangulasi metode, triangulasi sumber, pengecekan anggota, dan ketekunan pengamatan. Teknik analisis data menggunakan teknik analisis data interaktif yang dikembangkan Miles \& Huberman (1992).

Hasil analisis data dan studi pustaka pada tahap ini dilanjutkan dengan pembuatan desain awal produk materi ajar. Prototip pemateri ajar ini divalidasi pakar dalam FGD, yang selanjutnya direvisi sesuai masukan dari FGD. Sebelum produk awal ini digunakan terlebih dahulu dilakukan uji coba terbatas untuk mendapatkan informasi kelayakan. Produk awal ini direvisi lagi dengan memperhatikan masukan pakar dalam FGD. Setelah produk ini dinilai layak, dilakukan uji coba luas untuk menyempurnakan produk sebelum menjadi produk akhir.

Setelah teruji keefektifan model, langkah selanjutnya adalah diseminasi. Hasil diseminasi dilakukan dengan cara penerbitan buku materi ajar, pembuatan CD rekaman, pementasan drama sebagai pendamping materi ajar, presentasi seminar nasional/internasioanal, dan penulisan artikel di jurnal nasional terakreditasi atau jurnal bereputasi internasional. 
Suryato, Pengembangan Materi Ajar Mata Kuliah Apresiasi Drama $\mid 211$

\section{HASIL DAN PEMBAHASAN}

Nilai-nilai pendidikan karakter secara tersurat dan tersirat telah ditemukan di dalam naskah drama. Dari delapan belas nilai yang dikemukakan oleh Wibowo yang diinternalisasi dalam pendidikan karakter (2013:14-15), telah ditemukan sembilan nilai yang dapat dipaparkan berikut ini.

\section{Religius}

Religius merupakan suatu karakter yang mencerminkan tentang ketundukan terhadap Tuhan Yang Maha Esa. Karakter tersebut memaparkan suatu watak yang selalu bergantung pada Sang Pencipta dan berpegang serta berpedoman teguh pada Tuhan semesta alam. Kemendiknas (2010) menjelaskan bahwa religius merupakan sikap dan perilaku yang patuh dalam melaksanakan ajaran agama yang dianutnya, toleran terhadap pelaksanaan ibadah agama lain, dan hidup rukun dengan pemuluk agama lain. Kepatuhan itu mencakup segala kebiasaan sehari-hari, yakni bertingkah laku, bertindak, bersikap, serta berucap.

Dalam naskah drama ini ditemukan seorang Ibu yang berdoa di malam hari menyerahkan segala kepada Sang Pencipta tentang persoalan yang sedang dihadapi oleh kedua anaknya sebagai pangeran. Hal ini dapat diperhatikan pada cuplikan berikut.

\section{Kenari:}

Duh Gusti, lindungilah nyawa anak-anakku. Mereka anak yang baik. Patuh dan setia. Mereka menghormati ayahanda mereka dan juga menyayangi saya sebagai ibu.

Duh, anak-anakku, surat kalian telah ibu terima. Ibu senang kalian kenangkan di dalam pertempuran. Selama kalian pergi ibu puasa dan semedi. Tunaikan tugas kalian baik-baik secara wajar. Janganlah kalian punya keserakahan! Jangan kalian mengejar kedudukan. Kita sudah punya derajat tinggi. Apa adanya saja kita terima. Orang yang bernasib jelek berusaha memperbaiki nasibnya. Tapi, nasib kalian sudah baik. Lahir sebagai Pangeran dan pandai menjalankan kewajiban. Sudah itu saja cukup. Jangan kalian ikut gerakan yang mokal-mokal. Serahkan hal yang tidak beres kepada yang yang berhak dan berkewajban mengatur. Kalian urus saja bagian kalian baik-baik dan lalu pulang, beristirahat, dan bergembira bersama ibu.

Kekhawatiran Ratu Kenari terhadap anaknya sangat tampak dalam memanjatkan doa di tengah malam. Kepasrahannya kepada Tuhan terlukis, seperti Ratu Kenari telah menerima surat akan bahaya yang dihadapi putranya. Dalam doa itu juga berisi tentang pengingat bahwa putranya harus bersyukur atas apa yang telah dikaruniakan Tuhan.

Rendra menampilkan sosok tokoh ibu yang selalu mendorong anak-anaknya untuk berbuat baik. Dorongan tersebut terlukis dalam doa agar selalu menerima dan mensyukuri nikmat yang telah diberikan Tuhan serta tidak kufur atas nikmat-Nya. Secara psikologis, karakter sosok ibu ini berpengaruh pada kemampuan pribadi dan keberfungsiannya secara moral. Sebab, kekuasaan telah menjadi berhala bagi kehidupan keluarga keraton sehingga persaudaraan sedarah harus bercucuran karena diperebutkan. Ketakutan Ratu Kenari atas kejadian seperti itu membuatnya selalu berdoa dan mendekatkan diri pada Sang pencipta.

\section{Kerja Keras}

Kerja keras merupakan perilaku yang menunjukkan upaya sungguh-sungguh dalam mengatasi berbagai hambatan selama menjalani suatu hal dan pada muaranya dapat menyelesaikan tugas dengan sebaik-baiknya. Menurut Samani \& Haryanto (2012: 133), kerja kerasmerupakan "keyakinan akan adanya manfaat moral serta kecakapan melekat 
yang diperoleh dari bekerja sehingga dapat memperkuat karakter. Manusia yang termotivasi untuk bekerja keras akan mempertaruhkan apa yang dimiliki karena telah memahami bahwa hasil kerja ke-rasnya akan menuai hasil yang hebat. Karakter seperti itu selalu melekat pada diri manusia. Karakter kerja keras tercermin pada tokoh bernama Reso. Rendra mengomunikasikan karak-ter kerja keras dengan jelas dapat dilihat pada cuplikan berikut ini.

\section{Reso :}

Kelelawar sudah mulai terbang ke arah barat. Hari hamper terang tanah. Selamat berpisah, teman. Ingat, kita semua sudah penuh dengan tekad dan semangat, tetapi kitaakan menang bila memakai siasat. Selamat!

Bentuk kerja keras yang dilukiskan Rendra dalam tokoh Reso, yakni kemenangan akan dicapai bila menggunakan siasat. Semangat membara dan tekad kuat tidaklah berarti bila siasat yang digunakan itu salah yang menjadikan watak Reso sebagai pekerja keras.

\section{Reso :}

Rasa kuatir dan gamang racun yang berbahaya bagi hidup manusia. Barangkali tidak mematikan, tetapi melumpuhkan. Pejamkan matamu, Nyi Mas! Apa yang telah terjadi sepanjang hari ini justru kebalikan dari kekuatanmu, semuanya serba lancar.

Namun jangan kamu ragukan kewaspadaanku: Nyi Mas! Cita-citaku bukan sekedar untuk diri sendiri. Negara sedang merosot pamornya. Hanya para Panji dan Adipati yang masih sadar harus memberi kehidupan kepada rakyat. Kami berani hidup prihatin dan sederhana. Kami ingin jujur di dalam mengurusi perbendaharaan negara!

Watak kerja keras merupakan bentuk semangat kebangsaan yang tumbuh di dalam diri Reso. Kekacauan kerajaan membuat Reso bergerak agar dirinya yang menjadi Raja. Seperti tertera dalam kutipan "Nyi Mas! Cita-citaku bukan sekedar untuk diri sendiri. Negara sedang merosot pamornya. Hanya para Panji dan Adipati yang masih sadar harus memberi kehidupan kepada rakyat. Kami berani hidup prihatin dan sederhana. Kami ingin jujur di dalam mengurusi perbendaharaan Negara". Akan tetapi keinginan Reso justru mendapat penolakan keras dari istrinya. Persoalan rumit itu membuat Reso ingin menjadikan dirinya sebagai model pada orang-orang di sekitarnya. Hal ini selaras dengan pendapat Hidayatullah (2010: 41) bahwa model merupakan keteladanan yang lebih mengedepankan aspek perilaku dalam tindakan nyata daripada sekedar berbicara tanpa aksi. Ini ditunjukkan watak kerja keras Reso pada saat memimpin pergerakan dengan para panji melalui pernyataan-pernyataanyang membius.

\section{Reso:}

Baik. Aku akan tetap memimpin Gerakan Para Panji ini. - Jangan aku disiram dengan pujipujian lagi. Tetapi, beri aku keterlibatan kerja. Dan sekarang kita akan menetapkan pengeran mana yang akan kitacalonkan menjadi raja. Ada dua calon yangpunya dasar untuk bisa diterima oleh rakyat. Pertama Pangeran Rebo, kedua Pangeran Bindi. Sekarang, mari kita bicara.

Pelukisan karakter kerja keras seolah menjadi watak utama Panembahan Reso. Rendra melukiskannya melalui dialog antar tokoh. Para panji terbius dengan kata-kata 'Jangan aku disiram dengan puji-pujian lagi. Tetapi, beri aku keterlibatan kerja'. Hal tersebut jelas sekali menunjukkan sosok manusia pekerja keras, tidak mengedepankan pujian, akan tetapi mengedepankan kerja nyata. Reso memimpin gerakan itu untuk menentukan pangeran 
mana yang berhak menjadi raja. Selanjutnya, dalam penggalan dialog di bawah ini mengajarkan pada pembaca agar selalu memperjuangkan apa yang telah menjadi cita-cita.

Reso:

Itu bukan rencanaku dari semula. Itu suatu unsur yng tidak terduga yang ternyata sangat membantu rencanaku. Anda lihat, setiap rencana dan usaha kalau benar-benar diperjuangkan akan punya nasib sendiri. Nasib baik atau buruk, yang kita harus berani menanggung atau mensyukuri.

Reso menampilkan ungkapan di depan Panji Sekti, yakni tentang suatu muara bila bekerja keras. "setiap rencana dan usaha kalau benar-benar diperjuangkan akan punya nasib sendiri", usaha yang dilakukan manusia pasti menuai atau menghasilkan jerih payah yang diusahakan manusia. Setiap ikhtiar akan membentuk nasibnya sendiri. Seperti halnya pola aksi dan reaksi. Rendra mengajarkan kepada pembaca agar bekerja keras dan disiplin dalam membuat rencana karena hal itu yang akan membawa manusia pada suatu hal yang diinginkan.

Reso diciptakan Rendra dengan berbagai karakter dan watak yang bermacam-macam dengan menampilkan sosok positif dan sosok negatif. Watak-watak seperti itu membuat karya sastra lebih hidup dan bergairah. Banyak problematika, seperti halnya problematika di kehidupan nyata. Rendra seakan membuat refleksi yang pernah terjadi lalu mewujudkannya di dalam naskah. Pembaca dapat meneladani bentuk kerja keras untuk menuju kebaikan.

\section{Cinta Damai}

Nilai cinta damai merupakan suatu yang mendasari dari sikap, perkataan, dan tindakan yang menyebabkan orang lain merasa senang dan aman atas kehadiran dirinya. Lebih jauh Samani \& Haryanto berpendapat bahwa cinta damai merupakan "sikap dan perilaku yang menyukai harmoni dan bebas dari konflik dan gangguan, suka akan ketenangan" (2012:127). Nilai ini mengajarkan manusia untuk selalu menjauhkan diri dari konflik sosial maupun konflik internal. Konflik ini terjadi bermuara pada ketidak harmonisan hubungan antarmanusia.

Tokoh Nyi Reso memiliki karakter cinta damai, selalu berupaya menjauhi konflik. Nyi Reso orang yang pertama kali tidak setuju dengan cita-cita Reso ingin menaiki tahta kerajaan. Kecemasan dan kewaswasan makin tampak ketika Nyi Reso mengetahui cita-cita Reso. Nyi Reso membuat ketakutan di dalam pikirannya, membuat pertanyaan dan menjawabnya sendiri. Watak ingin menjauhi konflik dan selalu ingin bersama Reso, justru Reso tidak menyukai watak istrinya seperti itu. Sebenarnya Reso ingin minta dukungan pada istrinya, tetapi justru menjadi penghambat cita-citanya. Berikut kutipan yang mewakili watak Nyi Reso.

Reso:

Hm. Baiklah. Besok biar kamu diantar pulang ke orang tuamu. Semoga kamu mendapatkan kedamaian di sana. Sebenarnya, di manapun kamu tidak akan mendapatkan kedamaian, sebelum kamu bisa berdamai dengan dirimu sendiri. .....

Rasa damai membawa ketenangan bagi setiap manusia, membuat kenyamanan bagi kehidupan manusia. Manusia pastilah menginginkan hal yang nyaman, tentram, dan damai. Hal seperti itu tidak bisa dipungkiri menjadi fitrah manusia. Persoalan hidup sering 
membuat manusia jauh dari rasa damai. Nafsu ingin memiliki kekuasaan menjadikan diri manusia lebih tinggi drajatnya, justru akan menjadi persoalan yang menjauhkan manusia dari rasa nyaman, tentram, dan damai. Untuk itu, menurut Hidayat (dalam Zuchdi, dkk., 2009) bahwa manusia perlu melakukan life'sofjourney, yaitu upaya memahami kecenderungan sifat-sifat dasar watak atau karakter manusia.

Reso justru menjadikan dirinya selalu berdekatan dengan konflik, menjauhkan dari rasa nyaman, tentram dan damai. Kekuasaan telah menggiurkan dirinya untuk mendudukinya sehingga dalam kehidupan bertubi-bertubi muncul masalah. Sifat itu berkebalikan dengan karakter istrinya yang selalu mensyukuri apa yang telah menjadi prestasi dalam hidup Reso dan tidak menginginkan dirinya menjadi Raja.

\section{Gemar Membaca}

Gemar membaca merupakan kebiasaan menyediakan waktu untuk membaca berbagai bacaan agar memberikan kebajikan bagi dirinya. Kebiasaan membaca menjadi rutinitas untuk menambah ilmu pengetahuan. Bahan bacaan pun terkadang mempengaruhi pola hidup manusia. Secara tidak langsung bacaan yang telah terserap telah menjadikan pribadi manusia menjadi lebih berkarakter dan berkualitas. Salah satu karakter gemar membaca ditunjukkan oleh Pangeran Rebo, yang justru mendapat celaan dari baginda raja bahwa dirinya juga harus mengimbanginya dengan kegiatan olahraga. Berikut kutipannya:

\section{RajaTua:}

Terimakasih, Anakku, Pangeran Rebo. Kamu lihat aku masih tegar, ya? Tahu apa rahasianya? Olahraga! Aku lihat kamu pucat. Kurang olahraga.Terlalu banyak membaca. Seorang pemimpin harus banyak olahraga! Mengerti kamu?

Pangeran Rebo dikatakan oleh Raja Tua seorang yang terlalu sering membaca. Akibat kebiasaan membaca tersebut menjadikan Pangeran Rebo sebagai sosok yang meminimalkan peperangan. Tindakan Pengeran Rebo itu sangat selaras dengan konsep yang dikemukakan oleh Shanahan (1990) bahwa salah satu manfaat kegiatan membaca sebagai proses kognitif dapat memperkaya pengetahuan, bahkan memperkuat meta pengetahuan. Karena itu, wajar bila strategi perang yang diterapkan oleh Pangeran Rebo lebih mengutamakan perundingan. Hal tersebut justru membuat murka Sang Raja yang memiliki karakter keras dan tegas.

Dalam hal ini, Rendra tidak menjelaskan secara terperinci perkataan Pangeran Rebo yang suka membaca, kebiasaan-kebiasaan yang jelas bahwa dia suka baca. Rendra hanya mendeskripsikannya lewat perkataan baginda Raja, tidak lebih dari itu.

\section{Peduli Sosial}

Peduli sosial merupakan sikap dan tindakan yang selalu ingin memberi bantuan pada orang lain dan masyarakat yang membutuhkan. Kepekaaan manusia terhadap gejala sosial membutuhkan interaksi dengan orang-orang yang berada di sekitarnya. Hal inilah memberi kemungkinan proses memberi dan menerima. Penanaman nilai karakter yang berkaitan dengan kepedulian sosial dapat terlihat dalam naskah drama ini, seperti dikatakan Yuliawati (2012) bahwa "Karya sastra berkaitan erat dengan nilai sosial karena karya sastra dapat

pula bersumber pada nilai-nilai yang terjadi di dalam masyarakat. Nilai sosial mencakup kebutuhan hidup bersama, seperti kasih sayang, pengakuan dan penghargaan”. 
Nilai karakter peduli sosial tercermin di dalam perkataan Raja Tua saat perayaan ulang tahunnya. Seluruh pejabat kerajaan dihadirkan. Kepeduliannya tampak ketika menyampaikan ucapan terima kasih kepada Aryo Lembu seperti dalam kutipan berikut.

\section{RajaTua:}

Terimakasih, Aryo Lembu. Kita telah bersama-sama membangun negeri ini. Kita dulu bersama-sama mengusir penjajahan bangsa asing dari tanah air kita. Di hari inisaya tegaskan: janganlah kita mengurangi kewaspadaan. Bahaya penyusupan asing masih selalu mengancam. Karena itu para senapati harus mampu mendampingi aku dalam menjaga keutuhan Negara. Ingatlah pedoman pembangunan Negara yang telah kita tetapkan: Tertib, rapi, aman, dan sejahtera.

Kutipan di atas merupakan suatu hal yang mencerminkan tentang karakter kepedulian sosial. Kepedulian terhadap kepentingan kerajaannya. Raja mengungkapkan bahwa 'Kita telah bersama-sama membangun negeri ini. Kita dulu bersama-sama mengusir penjajahan bangsa asing dari tanah air kita'. Kebersamaan dalam mengusir penjajah menjadi simbol bahwa kerajaan yang dipimpin oleh Raja Tua sangat bersemangat untuk mempertahankan kerajaannya. Keutuhan daerah menjadi dasar kedaulatan kerajaan. Para pemberontak yang ingin memecah belah kerajaan dengan memperalat daerah yang telah dikuasi menjadikan kerajaan itu terombang-ambing dalam perpecahan. Kerajaan yang utuh tidak ada satu pun daerah yang terlepas. Raja Tua telah membuktikannya selama menduduki tahta. Banyak daerah yang disatukan dengan kerajaannya sehingga menjadi negara besar. Tertib, rapi, aman menjadi pedoman dalam pemerintahan Raja Tua.

Rendra menggambarkan sosok Raja Tua yang kejam dan sangar. Akan tetapi di sisi lain, Raja Tua sangat peduli dengan keutuhan kerajaannya. Kepedulian sosial atas keutuhan negara sangat ia jaga sehingga menampilkan sosok Raja yang sangat peduli atas kebutuhan kerajaan. Sikap-sikap kepedulian sosial Raja tua terhadap Pangeran, Arya, Senapati, dan Panji sangat tinggi. Terbukti Raja Tua selalu memberikan apresiasi khusus apabila salah satu dari pengabdinya mendapat prestasi gemilang. Kepedulian seperti ini patut diteladani pembaca dengan memberikan penghargaan kepada seseorang yang berprestasi sebagai wujud ungkapan berbangga hati atas apa yang telah diperoleh dengan tangannya sendiri. Kemampuan untuk mengintegrasikan kepentingan pribadi ke dalam kepentingan kolektif, menurut Soenarto (2004) akan melahirkan jiwa gotong royong yang telah mengakar dalam kehidupan masyara-kat, yang diwujudkan dalam bentuk sikap rila, narima, sabar, teman, dan budi luhur.

\section{Tanggung Jawab}

Tanggung jawab merupakan sikap dan perilaku seseorang melaksanakan tugas dan kewajiban, yang seharusnya dia lakukan terhadap diri sendiri, masyarakat, lingkungan (alam, sosial, dan budaya), negara, dan Tuhan Yang Maha Esa. Dalam hal apa pun manusia bertanggung jawab atas dirinya sendiri. Dalam hal lain, ia juga terkadang bertanggung jawab kepada orang lain, misal terhadap keluarga. Lickona mengatakan "nilai sikap hormat dan tanggung jawab sangat penting untuk: membangun kesehatan pribadi, menjaga hubungan interpersonal, membangun masyarakat yang demokratis dan berprikemanusiaan, dan membantuk dunia yang adil dan damai (2013: 61). Dalam kaitannya dengan naskah drama ini nilai tanggung jawab berimplikasi pada menjaga hubungan interpersonal.

Bentuk nilai tanggung jawab tersebut, yakni tanggung jawab seorang istri kepada suami yang memberikan pelayanan ketika suami di rumah. Nyi Reso menampilkan watak gemati 
terhadap Panji Reso. Rasa kasih sayangnya tulus tercermin dari ungkapan penawaran Nyi Reso yang ditampilkan sebagai seorang istri ideal, penuh perhatian, dan sayang yang mendalam. Nyi Reso yang benihnya kering belum bisa mengaruniai anak mencoba untuk membahagiakan suami dengan pelayanan yang baik. Pada prinsipnya, semua upaya yang dilakukan Nyi Reso merupakan pencerminan sosok pribadi yang baik dan telah ditunjukkannya sebagai kebiasaan. Menurut Elias (2010:47), kebiasaan itu meliputi penghargaan, tanggung jawab, integritas, kepedulian, keterbukaan, dan pemecahan masalah secara konstruktif.

Kekurangan Nyi Reso digantikan dengan rasa cintanya makin mendalam. Hal tersebut tampak ketika Reso menceritakan bahwa dirinya ingin menjadi Raja. Kepanikan, kegusaran, dan kegelisahan tampak pada pernyataan-pernyataan tidak setuju. Nyi Reso justru menginginkan Reso cukup menjadi panji yang dapat dipercaya Raja Tua, bukannya menjadi Raja.Ambisi yang ingin dicapai Reso pun tidak bisa dihalang-halangi oleh Nyi Reso. Reso sudah bertekat bulat ingin menjadi Raja walaupun menyebabkan pertempuran berlumur darah.

Wujud tanggung jawab Nyi Reso, yakni sebagai pengingat dalam mendampingi hidup suami. Nyi Reso selalu mengingatkan dengan penolakan keras bahwa dia tidak setuju jika Reso menjadi Raja. Alasan lain, Nyi Reso juga tidak ingin kehilangan Reso. Dia berpikiran sangat jauh saat Reso benar menjadi Raja dan beranggapan bahwa Reso akan menikah lagi, mengingat Nyi Reso tidak bisa mempunyai anak. Hal seperti itu tidak disetujui karena rasa cintanya amat dalam terhadap Reso. Pelukisan sosok istri yang bertanggung jawab dapat diperhatikan pada penggalan naskah di bawah ini.

Rumah PANJI RESO di waktu malam. NYI RESO sedang membuat "wiron" dua atau tiga kain. PANEMBAHAN RESO pulang.

Reso $\quad$ : Belum tidur, Nyi Mas? Hari sudah lewat tengah malam.

NyiReso : Ada kain yang harus saya wiru. Apakah makan malam saya dihidangkan sekarang, ataukah Kakanda mau mandi dulu?

Reso : Aku sudah makan dan mandi di istana.

NyiReso : Jadi, sudah ada yang mengurus Kakanda.

Reso : Hm.

NyiReso : Cantikkah ia?

Reso : Dua lelaki tua, si Kuncung dan si Bagong, pelayan di bangsal Kepanjen.

NyiReso : Lalu, pijat di mana?

Reso : Tidak pijat.

NyiReso : Kadang-kadang saya tergoda untuk pergi jauh-jauh ke luar dari rumah. Berjalan kemana saja hati saya mau. Tak perlu ada tujuan yang nyata. Masuk hutan, ke luar hutan. Masuk pasar, ke luar pasar.

Reso $\quad: \mathrm{Hm}$.

NyiReso : Apakah Kakanda menganggap wajar semua pertanyaan dan omongan saya?

Reso : Memang agak kacau isi pikiran kalimat-kalimatmu. 


\section{Demokratis}

Nilai demokratis merupakan nilai mendasar pada suatu keputusan bersama dalam memecahkan suatu permasalahan. Nilai ini tidak membeda-bedakan dalam membuat suatu keputusan. Usulan, saran atau pendapat mendapatkan posisi sama antara satu dengan lainnya. Ringkasnya, demokratis merupakan cara berpikir, bersikap, dan bertindak yang menilai sama hak dan kewajiban dirinya dan orang lain (Kemendiknas dalam Wibowo, 2013:15).

Bermusyawarah identik dengan demokrasi. Keputusan bersifat otoriter harus dihindari ketika demokrasi dilaksanakan. Keputusan secara mufakat dengan azas kebersamaaan, seperti ditemukan dalam naskah drama ini. Dengan kelihaian berbicara, Reso mengajak para Panji bermusyawarah untuk memutuskan siapa yang akan menjadi pemimpin. Untaian kata-kata, politis Reso membuat para panji andil membuat keputusan. Reso mampu menyihir para panjibahwa yang paling pantas menjadi pemimpin gerakan para Panji adalah dirinya.

Awalnya, Reso seakan menawarkan jabatan kepada semua Panji, sebelum dirinya ditawari oleh Panji lain. Kata-kata retoris yang dilontarkan Reso mengarahkan para Panji untuk memilihnya. Sosok Reso dilukiskan sebagai orang yang cerdik dan licik. Gerakan para Panji sangat berpengaruh dengan kondisi politik di kerajaan. Panji Tumbal sebagai pemberontak dijadikan alat intrik politik penurunan Raja Tua. Reso yang ahli membaca situasi dan mampu menelaah keadaan, pada akhirnya ia dapat menarik perhatian Baginda Raja Tua.

Dari awal gerakan ini didasari pada ketidakpuasan atas kepemimpinan Raja Tua. Panji Tumbal orang pertama yang mendeklarasikan untuk memberontak pemerintahan Raja Tua. Panji Reso memanfaatkan situasi tersebut dan mengarahkan para panji untuk memberontak. Panji Reso berpura-pura mendukung yang menjadi keputusan Raja, seolah menyihir Raja untuk mengikuti saran yang diusulkannya. Raja Tua menaruh kepercayaan kepada Panji Resodan kepercayaan tersebut dimanfaatkannya untuk menjatuhkan Baginda Raja.

Sebagai seorang Panji, Reso tega mengorbankan Panji Tumbal untuk menjatuhkan Raja Tua. Reso menjanjikan seribu tali emas untuk Panji Tumbal sebagai bentuk simbolis bahwa ia setuju atas pemberontakan tersebut. Akan tetapi dengan muka lain Panji Reso dihadapan Baginda Raja serta para panji mengutarakan persepsi berbeda dari sebelumnya.

Nilai demokratis dimanfaatkan Reso untuk mengukuhkan dirinya menjadi pemimpin. Nilai demokrasi menjadi alat untuk mendapatkan tempat. Dengan bahasa-bahasa persuasif menjadikan nilai demokratis itu makin cantik. Dalam naskah tersebut, Rendra memberi pelajaran kepada pembaca bahwa suatu kebaikan dapat difungsikan untuk kemungkaran. Rendra mengenalkan nilai demokrasi pada sisi berbeda. Tidak semata nilai kebaikan saja, tetapi nilai kebaikan juga digunakan untuk menyelimuti kejahatan. Lestyarini (2012:346) menjelaskan bahwa dalam masyarakat multikultural, properrelation menjadi unsur penting yang senantiasa diiringi dengan sikap dan watak yang membentuk interaksi yang tidak lain merupakan wujud perilaku demokrasi. Lebih jelasnya dapat diperhatikan pada kutipan berikut. 


$\begin{array}{ll}\text { Simo } & \text { : Kita tak bisa berkumpul terlalu lama. } \\ \text { Reso } & \text { : Tenang, Panji Simo! Sebelum terang tanah, kita sudah bubar. } \\ \text { Ombo } & \text { : Kita teliti dulu, apa ada mata-mata di antara kita. Kalau ada kita bunuh dia di } \\ & \text { sini sekarang juga. } \\ \text { Reso } & \text { : Tenang, Panji Ombo! Aku menyiapkan rapat ini dengan teliti. Semua yang } \\ & \text { hadir di sini aku dapat namanya dari Panji Tumbal. Dengar, Anda semua telah } \\ & \text { setuju untuk mendukung pemberontakan Panji Tumbal. } \\ \text { Wongso } & : \text { Tapi, kita telah kalah langkah berkat Ratu Dara keparat itu. } \\ \text { Bondo } & \text { Aku masih berani minggat dari sini dan terang-terangan menyusul } \\ & \text { pemberontakan } \\ \text { Reso } & : \text { Jangan! Panji Bondo, tahan dulu semangat Anda. Menurut pendapatku salah } \\ & \text { langkah sudah terjadi waktu Panji Tumbal mengirim surat ke istana. Pada } \\ & \text { intinya: pemberon-takan harus dimulai dari ibu kota, tidak dari Kadipaten. } \\ & \text { Dan, harus langsung merebut tahta, mengganti ganti pemerintahan. Baru } \\ & \text { kemudian semua kadipaten mendukung pemberontakan ini dengan serentak. } \\ & \text { Bila pemberontakan dimulai dari kadipaten, maka pemberontakan semacam itu } \\ & \text { hanya bersifat memisahkan diri dari kerajaan. Ini lemah! Ini hanya sekedar } \\ & \text { menentang raja, tetapi belum tentu mampu mengganti peme-rintahan. ..... }\end{array}$

Bondo : Jadi, sekarang kita akan mencetuskan pemberontakan di sini?

Reso : Sabar! Sekarang belum saatnya kita berontak. Para Aryo dan Senopati belum tentu berada di pihak kita. Dan, juga para Pangeran masih belum kita perhitungkan.

Sekti : Jadi, bagaimana dengan Panji Tumbal? Apakah ia akan kita biarkan seorang diri?

Reso : Apa boleh buat! Panji Sakti, kita pilih kehilangan satu jari atau seluruh tangan kita?

\section{Semangat Kebangsaan}

Semangat kebangsaan merupakan suatu motivasi yang timbul di dalam benak manusia untuk memajukan bangsanya dan kepentingan bersama. Semangat ini timbul karena banyak faktor yang mendorongnya untuk itu. Salah satunya, yakni banyak hal yang berkaitan dengan negara yang harus dibenahi. Seseorang di dalam dadanya sudah tertanam jiwa nasionalisme, berpatriot maka dia akan rela mengorbankan apa saja demi kemajuan dan kesejahteraan bersama. Kemendiknas (dalam Wibowo, 2013: 15) menjelaskan bahwa semangat kebangsaan merupakan cara berpikir, bertindak, dan berwawasan yang menempatkan kepentingan bangsa dan negara di atas kepentingan diri dan kelompoknya.

Dalam naskah drama ini ditemukan unsur semangat kebangsaan pada sosok Pangeran Rebo, anak pertama dari Raja Tua. Pangeran Rebo sosok pangeran yang dikatakan oleh Raja Tua suka membaca. Dalam cerita ini, jika menyelesaikan suatu permasalah cenderung dimusyawarahkan secara baik-baik daripada menumpasnya secara langsung. Pada saat memberi usul kepada Baginda Raja dan pada saat Panji Tumbal menyatakan pemberontakan, Pangeran Rebo mengusulkan agar berunding secara baik-baik agar tidak ada pertumpahan darah di kerajaan. Akan tetapi Baginda Raja justru menolak keras, apa yang dikatakan Pangeran Rebo tidak tepat sehingga Baginda Raja pun menganggap suatu sikap yang lemah. 
Sudut pandang antara Raja dan Pangeran Rebo dalam memecahkan masalah Panji Tumbal memiliki tujuan sama, yakni agar keutuhan negara tetap terjaga. Baginda Raja lebih otoriter, perintah yang difirmankan harus dilaksanakan segera. Dalam pandangan Baginda Raja dapat dikatakan sebagai pandangan garis keras. Apabila ada yang menganggu keutuhan negara harus dipengggal kepalanya. Semangat kebangsaan baginda mempertahankan keutuhan kerajaan sangat baik, sikap otoriter membuat Baginda seakan kejam. Segala sesuatu harus diselesaikan dengan pertumpahan darah. Hal tersebut justru menjadi momok menakutkan ba-gi rakyat. Rakyat segan karena takut keotoriteran Baginda Raja.

Pangeran Tumbal memberontak disebabkan keangkuhan Raja, kezaliman dilakukan Raja terhadap rakyat. Pangeran Tumbal menyatakan bahwa Raja Tua sekarang justru membuat rakyat sengsara. Kemiskinan meraja lela, tetapi di istana justru banyak orang berfoya-foya. Hal tersebut disayangkan oleh Pangeran Tumbal kepada Baginda Raja. Semangat kebangsaan juga ditunjukkan oleh Panji Tumbal pada penggalan kutipan berikut ini.
Tumbal : Maaf, Pangeran, apa boleh saya bicara?
Rebo : :(berhenti dan menanggapi) Ah, Panji Tumbal! Tentu saja. Tetapi kenapa mesti disini?

Tumbal : Ini mendesak. Dan ...darurat.

Rebo :Oh!

Tumbal : Begini, Pangeran Rebo, Baginda sudah tua. Apakah Anda tidak ingin menjadiraja?

Rebo : Lho, apa ini ....?

Tumbal : Negara kacau. Rakyat hidup di dalam kemiskinan. Kejahatan merajalela, baik di kalangan rakyat maupun di kalangan pejabat. Inilah saatnya Anda mengambil alih kekuasaan.

Rebo : Jangan kita berburu nafsu!

Tumbal : Apakah Anda tidak melihat?

Rebo : Saya melihat dan mendengar, tetapi pembangunan memang memakan waktu dan pengorbanan tak bisa kita hindarkan.

Tumbal : Tiba-tiba ucapan Anda lain dari biasanya.

Rebo : Jangan salah paham. Saya tidak suka bertindak dengan mata gelap. Semua harus mempunyai penalaran yang teliti. Bicaralah dulu dengan para pangeran yang lain, baru nanti kita bertemu lagi. Ayahanda Paduka Raja memang sudah rusak......

Semangat kebangsaan Panji Tumbal terlihat lewat pemberontakan yang dilakukan kepada Baginda Raja. Pemberontakan yang dilakukan oleh Panji Tumbal tidak semata-mata mengincar kekuasaan. Akan tetapi sekadar mengingatkan dan membela bahwa banyak rakyat yang sengsara, kemiskinan, dan kejahatan merajalela dimana-mana. Semangat kebangsaan tersebut justru disambut baik oleh Pangeran Gada dan Pangeran Dodot. Mereka berdua menyambut baik gagasan Panji Tumbal.Semangat kebangsaan seperti ini yang seharusnya terjalin di kalangan kerajaan. Menyejahterakan rakyat, membela kepentingan rakyat serta menumpas segala kejahatan. Panji Tumbal sebagai simbol seseorang yang merajut kebaikan di atas tumpukan kezaliman. Seperti halnya bangsa Indonesia ini, 
semangat kebangsaan untuk menegakkan kebenaran justru seakan ditimbun rapat-rapat oleh aparat pemerintahan. Orang-orang yang dianggap mumpuni di bidang penegakan hukum dikambinghitamkan dan dijebloskan tahanan. Pengalihan kasus menjadi tren untuk menyelimuti kejahatan yang kemudian lenyap.

Semangat kebangsaan untuk membela kepentingan tanah air memang perlu dijaga dandilestarikan. Tokoh Panji Tumbal menjadi contoh sosok nasionalis pembela kaum tertindas dan mengingatkan pada kaum penguasa melalui pemberontakannya. Rendra menjadikan Panji Tumbal sebahgai tokoh penebar benih kebaikan di atas tumpukan sampah. Raja Tua. Pangeran Rebo, dan Panji Tumbal masing-masing ingin mewujudkan kerajaan yang utuh, kuat, dan sejahtera. Hal ini salaras dengan pendapat Triyono (2012) bahwa pendidikan karakter dimaksudkan untuk mengembangkan kemampuan dan membentuk watak serta peradaban bangsa yang bermartabat dalam rangka mencerdaskan kehidupan bangsa.

\section{Menghargai Prestasi}

Menghargari prestasi merupakan wujud pengakuan atas keberhasilan seseorang dalam menjalankan amanah. Prestasi yang dihargai menjadikan motif untuk berprestasi lebih baik lagi. Menurut Kemendiknas (dalam Wibowo, 2013: 15), menghargai prestasi merupakan sikap dan tindak yang mendorong dirinya untuk menghasilkan sesuatu yang berguna bagi masyarakat, dan mengakui serta menghormati keberhasilan orang lain.

Pendidikan karakter mengajarkan untuk selalu menghargai apa pun dan siapa pun yang selalu berdampingan dengan manusia. Penghargaan tidak semata berwujud materi, tetapi dapat berwujud perlakuan, pujian, dan tepuk tangan. Dalam karya sastra diperlihatkan nilai pendidikan karakter. Karya sastra mendidik manusia melalui hal yang tersirat. Dalam naskah drama ini ditemukan nilai pendidikan karakter menghargai prestasi. Satu hal yang harus diperhatikan dalam pengondisian di sekolah, menurut Mumpuniarti (2012: 255), dalam menghargai prestasi itu hendaknya berdasarkan keunikan masing-masing siswa.

Rendra menampilkan sosok Raja Boneka yang ringan tangan dalam memberikan penghargaan kepada Panji, Arya, Senapati, dan Pemangku Raja. Keberhasilan para Panji mengukuhkan Pangeran Rebo menjadi Raja mendapatkan apresiasi sangat baik. GelarparaPanji diganti dengan gelar Arya dan juga mereka diberikan materi berlimpah yang dapat dijadikan penghidupan untuk mencukupi kehidupan keluarga dan sanak saudara.

Watak yang terlampau dermawan terlukis di dalam diri Pangeran Rebo. Kemudahan selalu diberikan untuk para pejabat kerajaan jika telah berjasa dan mempunyai prestasi membanggakan kerajaan. Seperti halnya Reso dan Ratu Dara, mereka dinikahkan atas titah Pangeran Rebo yang bertahta menjadi Raja. Titah sang Raja tidak terbantahkan dan tidak tertolak. Saat penitahan, Reso dan Ratu Dara juga sah menjadi suami istri.

Mendasar atas titah Maharaja, karakter menghargai prestasi ditemukan di dalam karakter Pangeran Rebo setelah menjadi Maharaja. Segala hal yang telah membantu penobatan dan berperan menstabilkan kerajaan mendapat apresiasi istimewa. Jasa-jasa yang diberikan untuk kerajaan mendapat penghargaan sangat hangat. Rendra menghadirkan karakter tersebut dalam diri Pangeran Rebo yang bertujuan untuk menunjang pandangan Raja Boneka yang diarahkan ke Pangeran Rebo kepada pembaca. 
Raja : Tentu saja aku juga tidak lupa berterimakasih kepada para Panji dan Adipati. Kepada kamu semua aku beri hadiah yang akan disampaikan oleh Aryo Sekti yang kini menjadi Senapati Istana, menggantikan Aryo Bungsu. Adapun Aryo Bungsu sekarang menjadi purnawirawan. Jasanya di masa lampau aku kenangkan dengan ucapan terima kasih. Para Adipati mulai besok sudah bisa pulang ke Kadipaten masing-masing. Aku ucapkan terimakasih......

Simo : Yang Mulia Sri Baginda Mahesa Kapuranta, hamba berterimakasih untuk hadiah dari Istana yang sudah sekian banyaknya. Sebetulnya hadiah kebendaan ini sudah terlalu banyak bagi hamba. Di Kadipaten hamba sendiri barang-barang itu sudah ada.

Raja : Tidak apa-apa. Nanti di rumah benda-benda itu bisa kamu bagi-bagikan kepada sanak keluargamu. Sebab aku juga tidak lupa untuk memperhatikan kesejahteraan keluarga para pembantuku.

Reso : Maaf, Yang Mulia, Paduka hampir lupa menyebut penghargaan yang lain untuk Adipati yang telah banyak membantu Paduka.

Raja : Ah, ya! Aku hampir lupa karena hadiah itu sifatnya hanya gelar belaka. Namun, gelaritu sifatnya resmi dan juga menurun kepada anak-anakmu. Kini sebagai Raja aku mengucapkan firman: Panji Simo, Panji Ombo, Panji Wongso, Panji Bondo, dan Panji Bolo, mulai sakarang aku beri gelar: Aryo Adipati Simo, Aryo Adipati Ombo, Aryo Adipati Wongso, Aryo Adipati Bondo. Inilah firmanku sebagai Raja.

Kesembilan nilai karakter ini menjadikan naskah drama Panembahan Reso sarat akan nilai kebaikan yang pantas digunakan untuk pembelajaran. Berdengungnya pendidikan karakter di Indonesia menjadikan hasil kajian nilai pendidikan karakter naskah drama Panembahan Reso ini menjadi prototipe penyusunan materi ajar mata kuliah Apresiasi Drama di perguruan tinggi. Prototipe materi ajar ini disusun dengan sistematika sebagai berikut: (1) Sampul buku luar menggunakan warna dan gambar tertentu yang menyatu secara estetik dan proporsional dengan penulisan judul buku dan nama pengarang; (2) Sampul buku dalam berisi kutipan UU tentang hak cipta, copyright buku, pencantuman penerbit, cetakan, dan pencantuman ISBN; (3) Kata pengantar; (4) Daftar isi; (5) Bab I, Hakikat drama dan pendekatan struktural; (6) Bab II, Analisis struktural naskah drama Panembahan Reso; (7) Bab III, Hakikat nilai pendi-dikan karakter dan nilai pendidikan karakter naskah drama; (8) Bab IV, Penutup; dan (9) Daf-tar pustaka. Selanjutnya, prototipe ini dimintakan pendapat pakar dalam FGD yang hasilnya diharapkan dapat menjadi media pendidikan bagi civitas akademika yang bergelut di bidang Bahasa dan Sastra Indonesia, khususnya yang terkait dengan kajian naskah drama.

Makin luasnya nilai pendidikan karakter yang digali dari naskah drama diterapkan dalam pembelajaran maka makin berhasil pula budi luhur anak Indonesia akan tercipta. Rendra sebagai salah satu sastrawan terkenal telah ikut berpartisipasi dalam pendidikan Indonesia melalui karya kreatifnya dalam wujud naskah drama.

\section{SIMPULAN DAN SARAN}

Berdasarkan hasil kajian nilai-nilai pendidikan karakter yang bertumpu pada tokoh dan penokohan dalam naskah drama Panembahan Resodi temukan sembilan macam nilai, yaitu: (1) religius, (2) kerja keras, (3) cinta damai, (4) gemar membaca, (5) peduli sosial, (6) tanggung jawab, (7) demokratis, (8) semangat kebangsaan, dan (9) menghargai prestasi. Atas dasar temuan tersebut dan mengingat perguruan tinggi juga berfungsi sebagai agen 
sosialisasi, maka hasil kajian ini dijadikan sebagai pengembangan materi ajar mata kuliah Apresiasi Drama. Dalam penelitian awal ini, pengembangan materi ajar masih berupa prototipe patut dipertimbangkan penggunaannya sebagai materi ajar, utamanya menjadi media pendidikan bagi para guru, dosen, dan mahasiswa yang berkecimpung di bidang pengajaran Bahasa dan Sastra Indonesia, terutama pada kajian naskah drama yang masih minim referensi. Selain itu, makin intensifnya nilai-nilai pendidikan karakter itu diterapkan di sekolah, keluarga, dan masyarakat memberikan peluang makin berhasilnya pembinaan budi pekerti luhur bagi tunas-tunas muda harapan bangsa melalui kajian karya-karya sastra Indonesia terpilih.

Berdasarkan simpulan di atas dikemukakan saran-saran kepada: (1) Penikmat naskah drama Panembahan Reso karya W.S. Rendra, baik ketika dibaca maupun dipentaskan hendaknya bisa meneladani hal-hal yang baik dan menghindari hal-hal yang kurang baik yang ada pada naskah drama tersebut; (2) Guru dan siswa hendaknya bisa menjadikan naskah drama Panembahan Reso ini menjadi salah satu alternatif bacaan karya sastra, khususnya drama di sekolah. Sebab, naskah drama ini tergolong sebagai naskah drama yang berkualitas; (3) Para pemimpin, baik di keluarga, lembaga maupun pemerintahan hendaknya dapat menyiapkan pembelajaran suksesi dengan sebaik-baiknya dengan cara memberikan kebebasan bependapat bagi semua pihak, agar proses suksesi bisa berjalan dengan baik, lancar, dan berhasil; (4) Penikmat karya sastra pada umumnya diharapkan membaca karya-karya yang berkualitas agar mendapatkan nilai-nilai yang berkualitas pula dari karya-karya sastra yang dibaca tersebut. Hal terpenting adalah berbagai nilai yang telah diperoleh dari kegiatan membaca karya sastra itu dapat diinternalisasi dalam bentuk sikap, perilaku, dan perbuatan baik di rumah, masyarakat maupun di sekolah sebagai seseorang yang memiliki kepribadian yang lebih baik dari kegiatan sebelumnya. Hasil internalisasi dari proses pembelajaran itu perlu diiringi keteladanan dari orang-orang dewasa di sekelilingnya dan pembiasaan yang memungkinkan munculnya perilaku dan sikap yang memiliki nilai.

\section{DAFTAR RUJUKAN}

Dewojati, C. 2012. Drama: Sejarah, Teori, dan Penerapannya. Yogyakarta: Penerbit Javakarsamedia.

Elias, M. 2010. Character Education: Better Students Better People. The Education Digest. (Online), (www.proquest.umi.pqd/web).

Gall, M. D., Gall, J. P., \& Borg, WR. 2003. Educational Research. Boston: Pearson Education, Inc.

Hidayatullah, F. 2010. Pendidikan Karakter Membangun Peradaban Bangsa. Surakarta: Yuma Pustaka.

Kementerian Pendidikan Nasional. 2010. Desain Induk Pendidikan Karakter. Jakarta Kemendiknas RI.

Lestyarini, B. 2012. Penumbuhan Semangat Kebangsaan untuk Memperkuat Karakter Indonesia Melalui Pembelajaran Bahasa. Jurnal Pendidikan Karakter. Tahun II Nomor 3, Oktober 2012, 340-354.

Lickona. 2013. Educating for Character, How Our School Can Taech Respect Approach. California: Woodsworth Publishing Company.

Miles \& Huberman. 1992. Analisis Data Kualitatif, Buku Sumber tentang Metode-metode Baru. Jakarta: UI Press. 
Mumpuniarti. 2012. Pembelajaran Nilai Keberagaman dalam Pembentukan Karakter Siswa Sekolah Dasar Inklusi. Jurnal Pendidikan Karakter. Tahun II Nomor 3, Oktober 2012, 248-257.

Rendra, WS. 1988. Panembahan Reso. Jakarta: Penerbit Pustaka Karya Grafita Utama.

Samani, M.\& Haryanto.2012. Konsep dan Model Pendidikan Karakter. Bandung: PT Remaja Rosdakarya.

Santrock, J.W. 1995. Live Span Development. Terjemahan Achmad Chusairi dan Yuda Damanik. Jakarta: Erlangga.

Sayuti, S. A. 2002. Sastra dalam Perspektif Pembelajaran: Beberapa Catatan dalam Sastra Masuk Sekolah. Riris K. Toha-Sarumpaet (Ed.). Magelang: Indonesia Tera.

Shanahan, T. 1990. Reading and Writing Together: What Does It Really Mean?. Shanahan (Ed.). Reading and Writing Together: News Perspective for the Classroom. Norwood, MA. Chritopher-Gordon Publishers.

Soenarto. 2004. Kebudayaan Jawa dan Perspektifnya. Makalah disajikan dalam forum Dialog Kebudayaan Nasional Kerjasama Pusat Syudi Badaya dan Puslit PKLH, Lemlit Universitas Negeri Yogyakarta, 8 Desember 2004.

Sudrajat. 2010. Membangun Budaya Sekolah Berbasis Karakter Terpuji. Pendidikan Karakter dalam Perspektif Teori dan Praktik. Darmiyati Zuchdi (Ed.). Yogyakarta: UNY Press.

Sutopo. 2002. Metodologi Penelitian Kualitatif: Dasar Teori dan Terapannya dalam Penelitian. Surakarta: Sebelas Maret University Press.

Suwandi, Sarwiji. 2011. Peran Sastra dalam Pendidikan Karakter bagi Peserta Didik. Makalah Seminar Nasional Sastra dalam Rangka Pekan Sastra Himprobsi, FKIP UNS

Suyanto. 2010. Urgensi Pendidikan Karakter. (Online), (http://www.mendikdasmen.depdik-nas.go.id) diakses 5 April 2014.

Toha-Sarumpaet, Riris K. (Ed.). 2002. Sastra Masuk Sekolah. Magelang: Indonesia Tera.

Triyono, S. 2012. Pengintegrasian Pendidikan Karakter dalam Pembelajaran Bahasa Jerman. Jurnal Pendidikan Karakter, Tahun II Nomor 3, Oktober 2012, 269-279.

Wibowo, A. 2013. Manajemen Pendidikan Karakter di Sekolah. Yogyakarta: Pustaka Pelajar.

Yuliawati, N. 2012. Analisis Stilistika dan Nilai Pendidikan Novel Bumi Cinta Karya Habibburahman El Shirazy. Skripsi tidak diterbitkan. Surakarta: FKIP Universitas Sebelas Maret.

Zuhdi, Darmiyati, (Ed.). 2009. Pendidikan Karakter: Grand Design dan Nilai-nilai Target. Yogyakarta: UNY Press.

Zuhdi, Darmiyati. (Ed.). 2011. Pendidikan Karakter dalam Perspektif Teori dan Praktik. Yogyakarta: UNY Press. 